\title{
The Mix of Monetary and Fiscal Policies: Conventional Wisdom Vs. Empirical Reality
}

\author{
KEITH M. CARLSON
}

T

HE current economic situation of high interest rates, high unemployment and large federal deficits has prompted a call for a change in the mix of stabilization policies. The current mix seems to be one of "easy" fiscal policy and "tight" monetary policy. Many analysts feel the mix should be shifted toward "tighter" fiscal policy and "easier" monetary policy, ostensibly for purposes of putting the economy on the path to recovery.

James Tobin, for example, recently stated that:

... the mix of policies is unhealthy. To achieve a solid recovery, such as the administration projects, and to achieve it without astronomical interest rates and serious crowding out, we need an easier monetary policy combined with a tighter fiscal policy."

Economists at the Brookings Institution have expressed a similar view:

Beyond 1982, the key to an improved economic situ" ation must lie in a realignment of economic policya shift in the mix of fiscal and monetary policy, by matching reductions of future budget deficits with an easier monetary policy. As presently constituted, fiscal and monetary policies appear to be on a collision course...

The Congressional Budget Office talks of the clash between monetary and fiscal policy:

Statements from the Federal Reserve suggest that monetary policy will continue its anti-inflationary

\footnotetext{
'James Tobin, "The Wrong Mix for Recovery," Challenge (MayJune 1982), p. 25

${ }^{2}$ Toseph A. Pechman and Barry P. Bosworth, "The Budget and the Economy, "in Joseph A. Pechman, ed., Setting National Priorities: The 1983 Budget (The Brookings Institution, 1982), p. 43.
}

stance in the coming years . . By contrast, the budget measures enacted last summer will provide considerable stimulus to economic activity over the next few years. This suggests the possibility of a clash between monetary and fiscal policy unless the Congress enacts further spending cuts and tax increases to reduce federal borrowing or the Federal Reserve adopts a less restrictive monetary policy. If the clash materializes, it will be reflected in high real interest rates that crowd out private investment. ${ }^{3}$

The notion of policy mix is well-known and has been a part of the macroeconomics literature for a number of years, but seldom has it generated controversy as it has now. Despite its recognition, however, little is known about the exact terms of the mix or what indicators of monetary and fiscal policy are most appropriate to use in defining it. For example, neither Tobin, the Brookings economists, nor the Congressional Budget Office state by how much fiscal policy should be tightened and to what extent monetary policy should be eased.

The gravity of the current economic situation requires that the notion of "policy mix" be given a more precise interpretation. Is current policy what it seems? How does one measure the ease and tightness of monetary and fiscal policies? What measures of economic performance are relevant to the mix argument-interest rates, GNP, the ratio of investment to GNP? What horizon is pertinent-short-run, longrun, a specific number of years? Can policies really be traded off to achieve a specific economic objective? These are the types of questions that are given short shrift when the mix of policies is discussed.

\footnotetext{
${ }^{3}$ Congressional Budget Office. The Prospects for Economic Recotery (U.S. Government Printing Office, 1982), p. 27.
} 
The purpose of this article is to provide some specificity to the policy mix question. As a point of departure, some indicators of monetary and fiscal policy are examined, and a historical classification of policy mix is developed. A conventional macroeconomic treatment of policy mix is then presented, providing the basis for development of testable hypotheses. These hypotheses are tested, and some policy implications are derived.

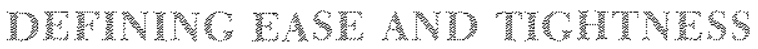 OF POLE}

Many summary measures of monetary and fiscal policy have been developed over the years. The main reason for seeking such a measure is to provide a quick interpretation of current policy stance. The criteria for selection are that the measure primarily reflect movements in the instruments of policy and that it not be influenced greatly by the pace of economic activity. ${ }^{4}$ In other words, the indicator should reflect the thrust of the policy on the economy rather than the reverse.

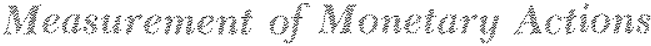

Measuring the stance of monetary policy revives many controversial issues, one of the oldest of which centers on the choice between interest rates and monetary aggregates. Although the level of interest rates is often alluded to as an indicator of monetary policy, most analysts have found it to be unreliable as a policy measure, since a great many forces influence interest rates besides monetary actions. The monetary aggregates, on the other hand, tend to reflect more accurately changes in the policy instruments-open market operations, reserve requirements and the discount rate-without being influenced unduly by out side forces. ${ }^{5}$

Chief among the candidates for a monetary policy indicator are the money stock (M1) and the monetary base. The monetary base has appeal because it reflects more accurately changes in the instruments of policy than does M1. The M1 measure, however, tends to be more closely related to GNP. ${ }^{6}$

\footnotetext{
${ }^{4}$ See, for example, Albert E. Burger, "The Implementation Problem of Monetary Policy," this Review (March 1971 ), pp. $20-30$.

5ee R. W. Hafer, "Selecting a Monetary Indicator: A Test of the New Monetary Aggregates," this Review (February 1981), pp. $12-18$

${ }^{6}$ For references to the literature, along with a contrasting interpretation, see William E. Cullison, "Money, the Monetary Base, and Nominal GNP," Federal Reserve Bank of Richmond Economic Review (May/Jine 1982), pp. 3-13.
}

Labeling monetary policy as easy or tight is, of course, quite arbitrary. The procedure followed here is to examine the historical record of $\mathrm{ML}$ and develop a classification of relatively easy and relatively tight policy on the basis of this record. To make this classification meaningful, one must account for changes in the trend of monetary growth, particularly if one intends to focus on the impact of monetary policy on real variables. Consumers and investors come to expect certain growth rates of the monetary aggregates, basing such expectations on past experience. It is the deviation of the monetary aggregate around this expected growth rate that affects real economic activity.

Table 1 summarizes monetary policy since 1956. The first column shows the four-quarter rate of change of $\mathrm{M} 1$ minus its trend (20-quarter rate of change) for the period ending in the fourth quarter of each year (except for 1982). "The second column, which classifies monetary policy as easy, tight or neutral, follows from a three-part division of the observations in the first column. The mean plus or minus $1 / 2$ standard deviation serve as points of demarcation. The classification is relative and also approximate. Rigidly adhering to the four-quarter rate of change can mask changes in policy that occur within the year. A more exhaustive study would not be tied to periods of fixed length. Nonetheless, the classification seems to accord with common interpretation of economic experience; for example, all of the observations labeled as "tight" occurred near recession periods.

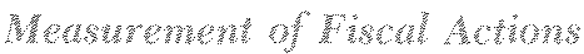

The measurement of fiscal actions also has been researched extensively over the years. ${ }^{5}$ The chief conclusion from this research is that recorded surpluses or deficits do not provide an accurate measure of fiscal actions. The reason is that a considerable amount of the movement of receipts and expenditures reflects an antomatic response to the pace of economic activity rather than policy actions. Consequently, only fiscal measures on a high-employment basis are considered $^{9}$ These high-employment budget measures

\footnotetext{
Justification for a 20 -quarter rate of change as a measure of trend is found in Denis S. Karnosky, "The Link Between Money and Prices," this Review (June 1976), pp. 17-23. See also Keith M. Carlson, "The Lag from Money to Prices," this Review (October 1980), pp. 3-10.

${ }^{8}$ Alan S. Blinder and Robert M. Solow, "Analytical Foundations of Fiscal Policy, "in Alan S. Blinder and Robert M. Solow, eds., The Economics of Public Finance (The Brookings Institution, 1974), pp. 3-115

${ }^{9}$ Frank de Leeuw and Thomas $M$. Holloway, "The HighEmployment Budget: Revised Estimates and Automatic Inflation Effects" Strvey of Current Business (April 1982), pp. 21-33.
} 


\section{Table 1}

\section{Classification of Ease and Tightness of Monetary and Fiscal Policy}

\begin{tabular}{|c|c|c|c|c|c|c|c|c|}
\hline \multirow[b]{3}{*}{ Year' } & \multicolumn{2}{|c|}{$\begin{array}{l}\text { Monetary } \\
\text { Measure }\end{array}$} & \multicolumn{6}{|c|}{ Fiscal Measure' } \\
\hline & \multicolumn{2}{|c|}{$\mathrm{Mt}_{4}, \mathrm{Mt}_{2}$} & \multicolumn{2}{|c|}{$\mathrm{E}^{\mathrm{H}}, \mathrm{E}^{\mathrm{H}}=0$} & \multicolumn{2}{|c|}{$\mathrm{B}^{\mathrm{H}}, \mathrm{E}^{\mathrm{H}} 4$} & \multicolumn{2}{|c|}{$\mathrm{s}_{\mathrm{YP}}^{\mathrm{H}} \mathrm{s}_{4}$} \\
\hline & value & Class & Value & Class & Value & class & Value & Class \\
\hline 1956 & $+1,19$ & t? & 584 & 世 & 215 & 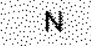 & 0.52 & I \\
\hline 1957 & 4167 & 1 & 6.83 & $E$ & 466 & $E$ & 0,69 & $E$ \\
\hline 1958 & 1,49 & E & 1012 & $E$ & 1005 & E & 1773 & $\varepsilon$ \\
\hline 1959 & 033 & $\mathrm{~N}$ & 671 & 1 & 8946 & t? & 1,72 & t \\
\hline 1960 & 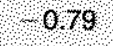 & 1 & 289 & 1 & 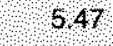 & 1 & 107 & T \\
\hline 1961 & 1,19 & e & 268 & $\mathrm{~N}$ & 4634 & $\mathrm{E}$ & 1,02 & $E$ \\
\hline 1962 & 0.30 & N & 175 & N & 202 & 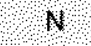 & 4032 & ॥ \\
\hline 1963 & 1,75 & E & 4122 & T & ४ै51 & 1 & 10,33 & $\mathrm{~N}$ \\
\hline 1964 & 471 & E & -382 & (1) & 1496 & $\mathrm{~N}$ & 0.38 & $N$ \\
\hline 1965 & 0.91 & 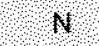 & 485 & $E$ & 834 & $E$ & -148 & $\mathrm{E}$ \\
\hline 9666 & 069 & 1 & 8.46 & E & 2,01 & $\mathbb{N}$ & 4048 & 1 \\
\hline 1967 & \४ & E & 2249 & $\mathrm{~N}$ & 3,46 & E & 4079 & E \\
\hline 1968 & 233 & E & 4008 & N & १? 89 & T & 4131 & 1 \\
\hline 1969 & $4 \longdiv { 0 8 }$ & 1 & 46.33 & 1 & 460 & I & 4114 & 1 \\
\hline 1970 & 40,16 & 1 & १४ & T & 4.59 & E & 14,32 & e \\
\hline 1971 & 40.87 & $\mathrm{~N}$ & ४४ 28 & 1 & 1229 & $\mathrm{~N}$ & -0.29 & $N$ \\
\hline 1972 & १ै.26 & E & 4603 & E & 45,34 & E & 4,15 & $\mathrm{E}$ \\
\hline 1973 & 4017 & 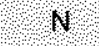 & ? 273 & 1 & 47.60 & $\mathrm{~T}$ & $14 \% 35$ & 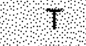 \\
\hline 1974 & 1435 & 1 & 46,32 & $\mathrm{E}$ & 4,43 & 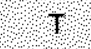 & 0,58 & 1 \\
\hline 1975 & 116 & I & 2,90 & $N$ & $\$ 8,9$ & E & \४67 & ? \\
\hline 1976 & 40,6 & $N$ & 4402 & T & 200 & $N$ & 40.30 & N \\
\hline 1977 & 1221 & E & 4022 & $N$ & $1+62$ & $\mathrm{~N}$ & 4045 & 4 \\
\hline 1978 & 4177 & E & ? 1.58 & 1 & 482 & T) & 0.81 & 1 \\
\hline 979 & 40.4 & N & 10.86 & N & 0.21 & N & 0.02 & U \\
\hline 1980 & 40.14 & $N$ & 656 & $F$ & 4062 & N & 0.05 & U \\
\hline 1987 & 4220 & 4 & 4031 & n & 1,34 & U & 0.030 & N \\
\hline 1982 & 211 & 18 & ? & 1 & 4,62 & $\mathrm{~B}$ & 4100 & E \\
\hline Mear & 0423 & & 4127 & & 40,7 & & 40.11 & \\
\hline Mean $/$ /or & 40.45 & & 4,00 & & 3014 & & 40.60 & \\
\hline Mean. 180 & 4092 & & 354 & & 220 & & 1038 & \\
\hline 4 fasy & N Ne: & & trot & & & & & \\
\hline
\end{tabular}

can be assembled in different ways, however. Three high-employment measures are examined: the rate of change of expenditures minus its trend, the rate of change of receipts minus the rate of change of expendi- tures, and the change of the surplus or deficit scaled by the size of the economy as measured by potential GNP. The latter two measures were tested for the presence of trend, but none was apparent. 


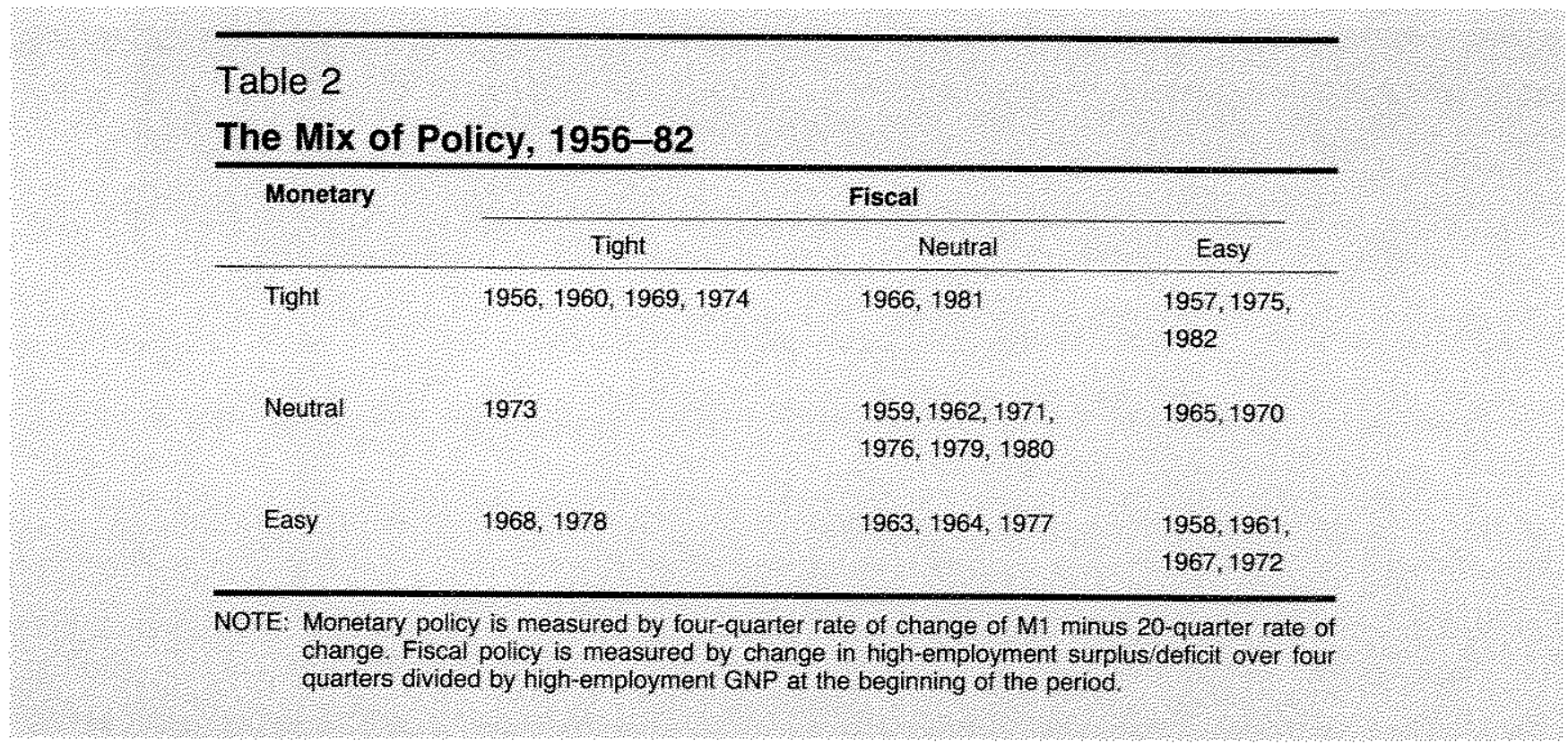

The right-hand portion of table 1 summarizes these three fiscal measures over the 1956-to-1982 period. The rate of change of high-employment expenditures is included because previous studies have used it as a summary fiscal measure even though it does not reflect changes in tax policy. ${ }^{10}$ The other two highemployment measures-the rate of change of receipts minus the rate of change of expenditures and the change in the surplus/deficit scaled by potential GNP-reflect changes in both tax policy and expenditure policy. In general, these latter two measures yield the same classification of easy, tight and neutral.

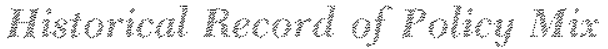

The measures of monetary and fiscal policy can be combined to give a classification of each year in terms of the mix of those policies. Table 2 provides this summary on the basis of detrended Ml and the highemployment surplus/deficit measure of fiscal action. The years shown in the corners of this matrix are most revealing. Periods when both policies were tight clearly were associated with recessions; those when both were easy were associated with economic expansion. The periods of contrasting policies, though few in number, are interesting nonetheless. Easy monetary policy and tight fiscal policy occurred only in 1968 and 1978 , both expansion years before business cycle peaks. The

\footnotetext{
${ }^{19}$ See Leonall C. Andersen and Jeny L. Jordan, "Monetary and Fiscal Actions: A Test of Their Relative Importance in Economic Stabilization," this Review (November 1968), pp. 11-24.
}

other extreme of tight monetary policy and easy fiscal policy occurred in 1957, 1975 and 1982; these were recession years, although all of 1975 is not classified so according to the National Bureat of Economic Research.

The current situation (note that 1982 refers to the four quarters ending in second quarter 1982) clearly falls into the classification of tight monetary policy and easy fiscal policy. According to the detrended measure of monetary policy as shown in table 1, 1981 and 1982 are the tightest years for monetary policy for the 195682 period. The measures of fiscal policy, however, do not indicate unusual ease. The expenditure measure does not indicate ease at all, and the other two, although suggesting ease, do not indicate that the degree of ease is unusual. There have been six or seven of the last 27 years (depending on which measure is used) when fiscal policy has been easier than in 1982.

The current concern about the mix of policies, however, is not focused entirely on the recent past (note, in particular, the quotations by Brookings and the Congressional Budget office above). There is concern abont the near future. In other words, given current trends, analysts seem to be most concerned about developing trends in the mix. Consequently, a full assessment of policy mix requires an extrapolation of trends to determine if the mix of policies appears to be worsening, that is, that monetary policy is tightening further or at least remaining tight, and that expenditure and tax policies are leading to a further easing of fiscal policy. 
Figure 1

Determination of Real Income, Interesi Rate and Investment-Saying Ratio

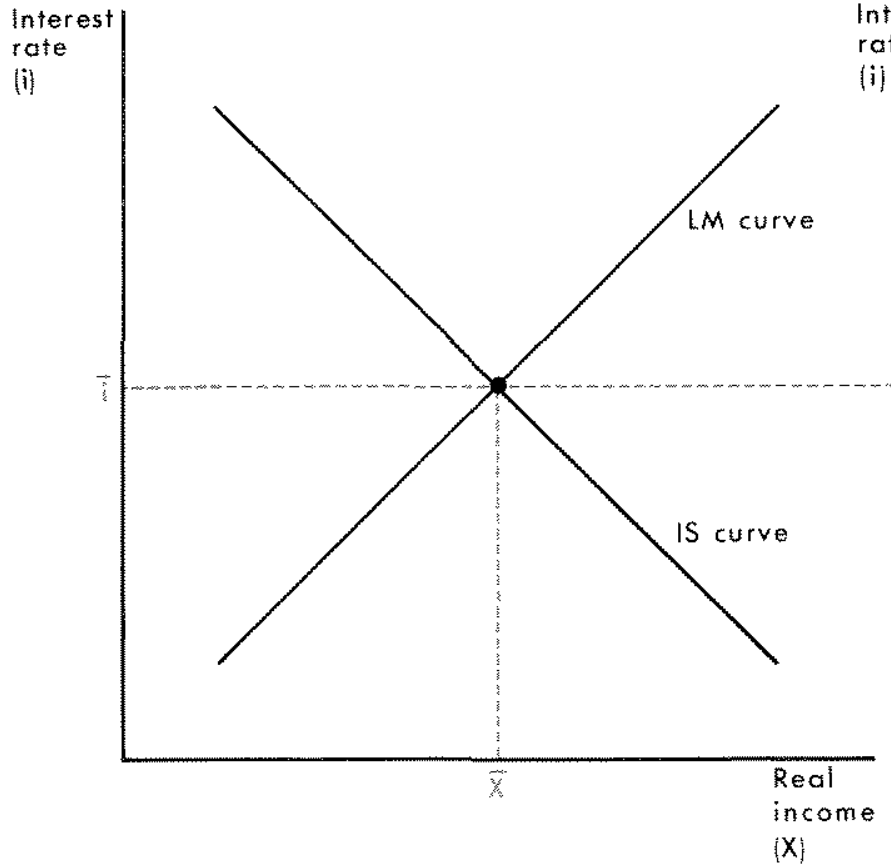

IS curve depicts equilibrium in goods and services market.

LM curve depicts equilibrium in money market

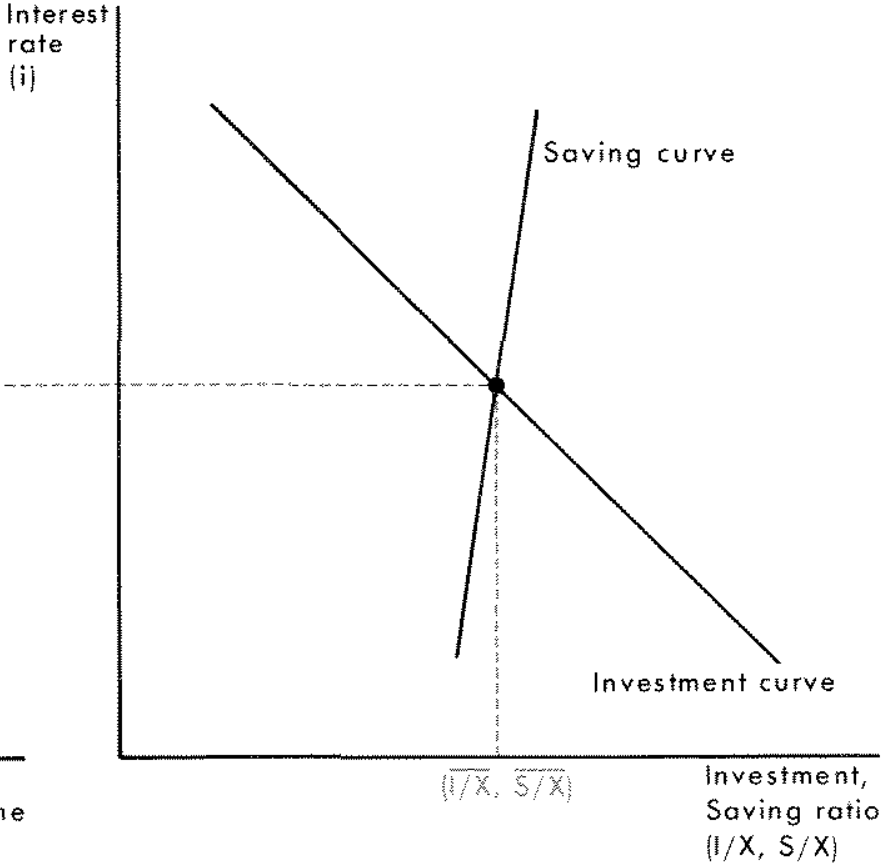

Investment and saving curves are drawn for given level of real income $(\bar{X})$.

\section{DEP

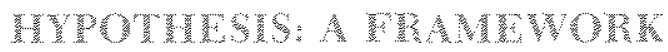

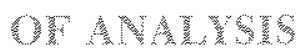

The question of policy mix is broad, encompassing a large body of macroeconomic theory and empirical support for the theory. Since a broad review of the theory is thus prohibitive, a typical example from macroeconomic textbooks is summarized to represent the policy-mix literature. ${ }^{11}$

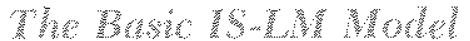

The notion of policy mix usually is explained by using the well-known Hicksian IS-LM framework. According to this framework, the level of economic activity (real income) and the level of interest rates are determined by the conjunction of conditions in two

\footnotetext{
Sisee, for example, Robert I. Gordon, Macroeconomics, 2nd ed. (Little, Brown and Company, 1981), pp. 140-42; or William $\mathrm{H}$. Branson and James M. Litvack, Macroeconomics, 2nd ed. (Harper and Row Publishees, 1981), pp. 86-90.
}

aggregate markets: the market for goods and services and the market for money. ${ }^{12}$ Fiscal policy, that is, changes in federal expenditures and tax rates, infuence the economy through the market for goods and services, while monetary policy works through the money market.

The IS-LM model is summarized in figure 1. The IS curve is the locus of combinations of interest rate and real economic activity consistent with equilibrium in the goods and services market. The curve is downward-sloping because lower interest rates induce higher levels of investment, which increase real income through the multiplier. Including the federal govemment in the analysis broadens the equilibrium condition to investment plus goverment purchases equals savings plus taxes. The right-hand panel shows explicitly the situation in the goods and services market that underlies the Is curve in the left-hand panel. Although in reality both savings and investment depend on real

\footnotetext{
${ }^{12}$ In the simplest version of the IS-LM model, there is no distinction made between nominal and rea interest rates becase the price level and price expectations are held constant.
} 
Figure 2

Policy Mix and the IS-LM Framework

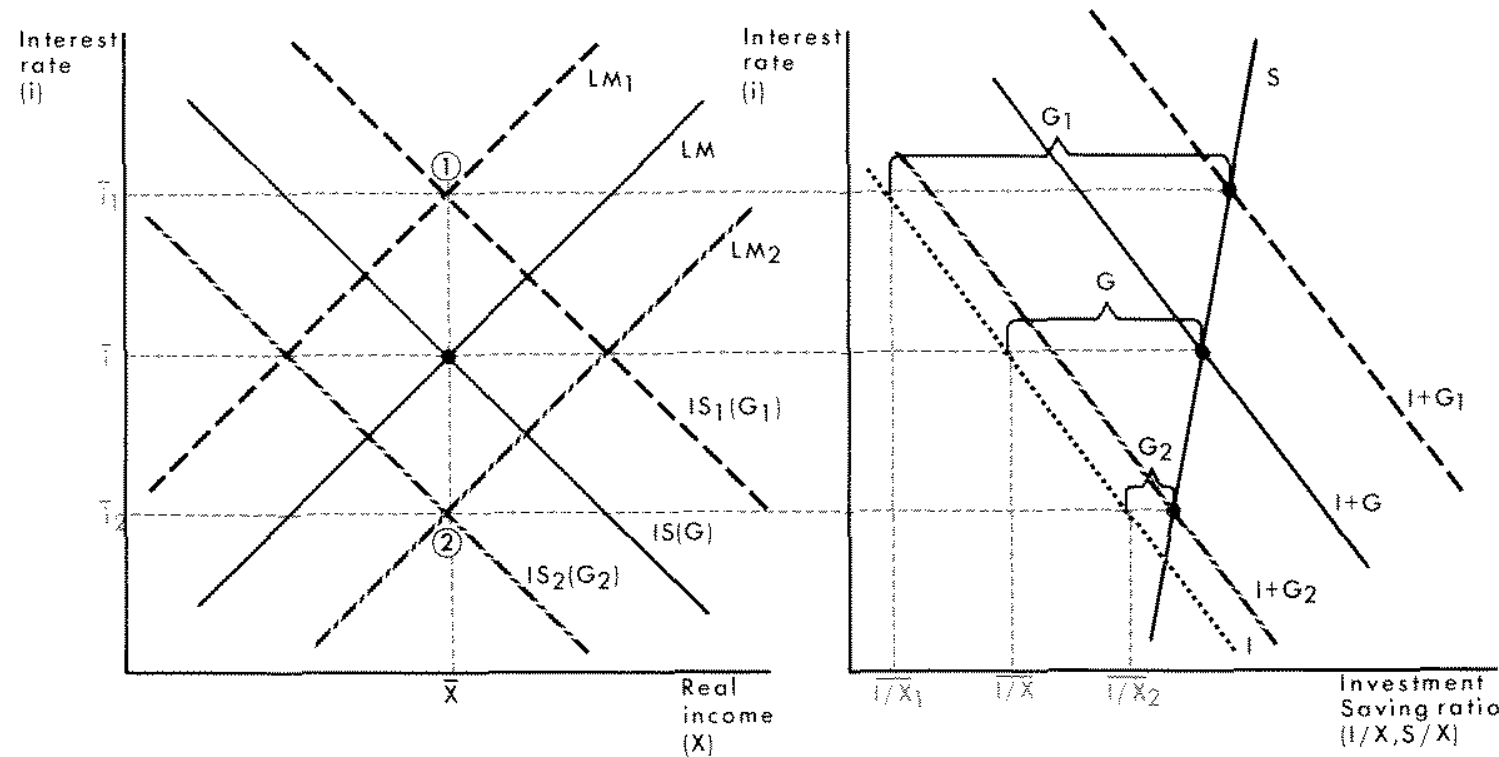

6) Tight monetary policy $\left(M_{3}, M\right)$ and easy fiscal policy $\left(G_{1}, G\right)$.

e) Easy monetary policy $\left(M_{2}>M\right)$ and tight fiscal policy $\left(\mathrm{G}_{2}, \mathrm{G}\right)$

income, the curves are drawn here only with reference to the equilibriam level of income.

The LM curve, as shown in figure 1, is the locus of combinations of interest rate and real economic activity consistent with equilibrium in the money market. Money is defined as currency plus checkable deposits. The carve is upward sloping because the demand for real balances is assumed to be negatively related to interest rates and positively related to real income. Consequently, in order for the demand for real balances to be equal to a fixed supply, an increased demand for money balances as real income increases must be offset by reduced demand for money balances via higher interest rates.

Real income and interest rates are determined simultaneously by the intersection of the IS and LM curves. Only this combination of interest rate and real income is consistent with equilibrium in both the goods and services and money markets. The way that this equilibrium combination changes in response to monetary and fiscal actions is of interest here.

Fiscal actions affect equilibrium by shifting the IS curve, while monetary actions shift the LM curve. Consequently, a given level of real income can be achieved with different combinations, or mixes, of monetary and fiscal actions. For example, in figure 2 , the combination of $\mathrm{IS}_{1}$ and $\mathrm{LM}_{1}$ represents "easy" fiscal policy and "tight" monetary policy, and a given level of real income is achieved with a higher interest rate than at the original equilbrium. Smilarly, the intersection of $\mathrm{IS}_{2}$ and $\mathrm{LM}_{2}$ reflects "tight" fiscal policy and "easy" monetary policy. "High" interest rates imply a lower rate of private investment (see righthand panel) and thus signify slower economic growth over the long term than a set of policies that yields "low" interest rates.

Within the context of the current economic situa tion, the implication seems to be that the U.S. economy is operating at a point corresponding to the intersection of $\mathrm{IS}_{1}$ and $\mathrm{LM}_{1}$. This interpretation, however, is not obvious. Rather, Tobin and Brookings economists seem to draw the conclusion that the eoonomic recovery cannot be started or sustained unless interest rates are reduced by changing the mix of policies. This interpretation suggests that they view the IS-LM framework in dynamic rather than in static terms. In other words, the level of real income and interest rates are being moved over time by a combination of policies in such a way that interest rates are rising-or at least being sustained at high levels. 
Figure 3

Inflationary Expectations and the IS-LM Framework

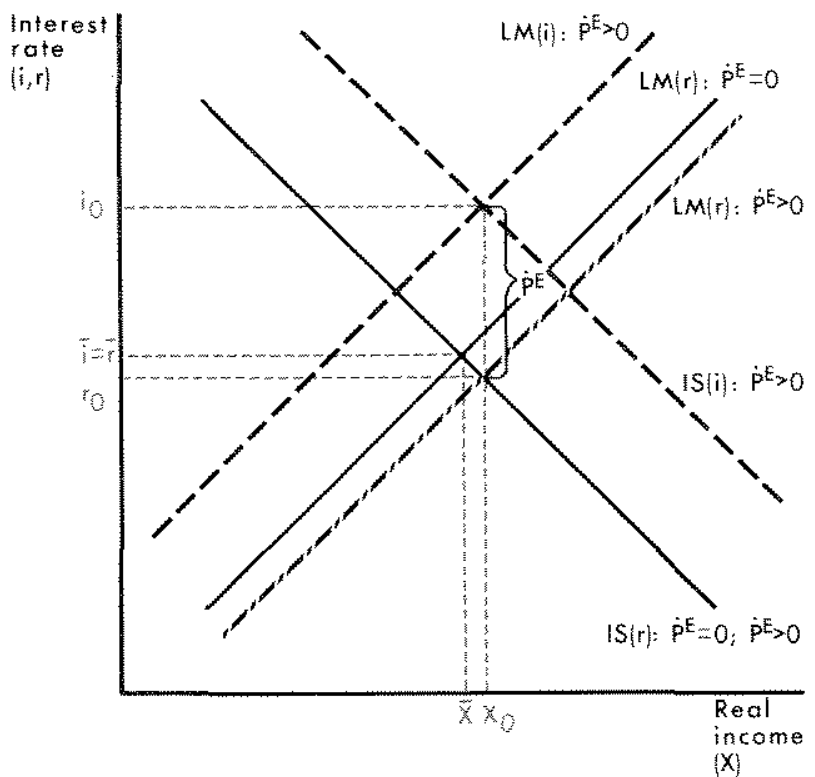

Infiationary expectations ( $\dot{\mathrm{P}}^{\mathrm{E}}$ o) push up nominal interest rate (i), but by less than $\dot{P}^{\mathrm{E}}$.

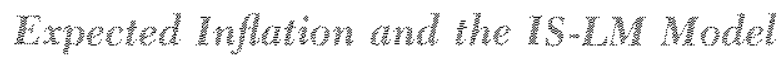

The version of the IS-LM model discussed above is based on a number of simplifying assumptions. One of the most important simplifications is that inflation and expectations of inflation can be ignored. It would seem that any discussion of current economic developments should be based on a framework that allows for the effect of expected inflation.

The effect of introducing expectations into the $\mathbb{I S -}$ LM model is shown in figure 3 . The interest rate axis now represents both nominal and real interest rates. $I S_{0}$ represents equilibrium in the goods and services market with expected inflation equal to zero (implying nominal and real interest rates are the same). The effect of introducing expected inflation of some positive amolnt is to shift the IS curve upward and to the right with respect to nominal rates, but leave it unchanged in terms of real rates. The reason for this is that consumption and investment decisions are assumed to be based on real rather than nominal rates of interest. This means that IS $_{1}$ is raised above $I S_{0}$ by the amount of expected inflation.

The effect on the L.M curve of introducing expected inflation is somewhat more complicated. If, for exam- ple, the demand for real balances depends on the difference between rates of return on money and all other assets, then expected inflation will affect all of these rates of retum equally, including the return on real balances, and the LM curve will not be affected when drawn in terms of the nominal interest rate. If the assumption of equal effects of expected inflation on all asset returns is relaxed, however, the results will differ. An increase in expected inflation generally can be expected to increase the nominal return on capital relative to bonds and money. Wealth-holders will attempt to rearrange their portfolios to hold more capital and less money and bonds. Prices of capital will rise as those on bonds fall; that is, interest rates will rise. This means the LM curve will shift upward when drawn with reference to the nominal rate of interest. Because all wealth is not affected by a change in expectations, however, the upward shift of the LM curve will be less than the change in expected inflation.

The effect on policy mix of introducing expectations into the IS-LM model depends on the response of expectations to any change in policy. If expectations do not change in response to a shift in policy, the mix can be changed as in the basic model. A given level of income can be achieved with different combinations of policies and different interest rates. On the other hand, if expectations are responsive to either monetary or fiscal actions, a larger number of possibilities is introduced, depending on the nature of the expectations response. In general, the faster expectations react to actual changes in monetary or fiscal policy, the less the effect of policy changes on the real variables, that is, real income, real interest rates and the investment ratio.

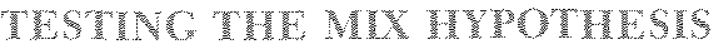

The IS-LM framework provides a rationale for assigning the mix of policy an important role in planning the course of economic activity. Though there are many problems involved in moving from the classroom blackboard to economic reality, the general framework can still serve as a guide in formulating a test of the nix hypothesis.

\section{Texhing proved the}

The question of policy mix focuses on the aggregative effects of monetary and fiscal actions and thus lends itself to a reduced-form approach to hypothesis testing. ${ }^{1.3}$ The details of the transmission mechanism

\footnotetext{
${ }^{13}$ See Andersen and Fordan. "Monetary and Fiscal Actions."
} 


\section{Table 3}

\section{Variables Used in Regressions}

\begin{tabular}{|c|c|c|}
\hline Dependent varable & Monetary & Fscal \\
\hline Aaa corporate Aaa & $\begin{array}{l}\text { M1 compounded annual } \\
\text { ate of change of } \\
\text { money stock narrowly } \\
\text { defined }\end{array}$ & $\begin{array}{l}\text { El conpounded annual } \\
\text { rate of change of high } \\
\text { employment federal } \\
\text { expenditures }\end{array}$ \\
\hline Aad P n Aarate & & 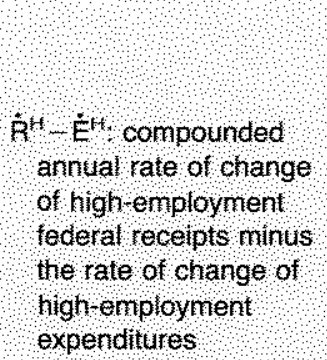 \\
\hline $\begin{array}{l}\mathrm{x}()_{\text {, change in the ratio }} \\
\text { of fixed investment } \\
\text { o GNP }\end{array}$ & & 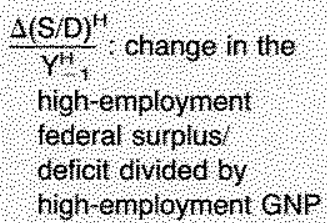 \\
\hline
\end{tabular}

NOTE All variables are expressed in percent terms

from a policy action to economic activity are of secondary interest, as is the process by which inflationary expectations are formed. Rather, the chief concern is whether certain values of key economic variables can be achieved with different combinations of monetary and fiscal actions.

The variables used in the analysis and summarized in table 3 are restricted to those implicit in the IS-LM framework. The dependent variables are real GNP, real and nominal interest rates, and the ratio of fixed investment to GNP. These variables were regressed on current and lagged values of the monetary and fiscal variables. ${ }^{14}$ The regressions involving interest rates demonstrated substantial autocorrelation in the residuals, so these equations were adjusted using the Cochrane-Orcutt procedure. All other equations were estimated with ordinary least squares. Lag length was

\footnotetext{
${ }^{4}$ Although $M$ minus trend was used in table 1 in defining the stance of monetary policy, M without trend adjustment was used in the regressions, manly because of its simple interpretation. Explaining the quarter-to-quarter variation of a variable is little affected by this choice, except for the value of the constant term.
}

determined by varying the lag by multiples of four and choosing from these regressions on the basis of maximum adjusted $\mathrm{R}^{2}$. The Almon lag technique was used, with the coefficients constrained to lie on a thirddegree polynominal with a tail constraint. These estimates were tested against the unrestricted leastsquares estimates to ensure that the smoothness assumption could not be rejected by the data.

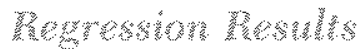

Tables 4-7 summarize the statistical results. The effects of the policy variables on the relevant dependent variable are summarized as one-year effect, twoyear effect and full effect. The final colum, labeled "mix effect," of tables 4-7 is of particular interest here. The mix effect is defined as the percentage change in M1 that would be required to offset a tighter fiscal policy and keep the dependent variable constant. $A$ tighter fiscal policy is defined as a decrease in federal spending that would increase the change in the highemployment budget by $\$ 5$ billion for 1980 and 1981 . An appendix provides the specifies of how this tighter fiscal policy is defined. 


\section{Table 4}

\section{Effects of Monetary and Fiscal Actions on the Aaa Bond Rate} Sample Period: II/1959-IV/1981

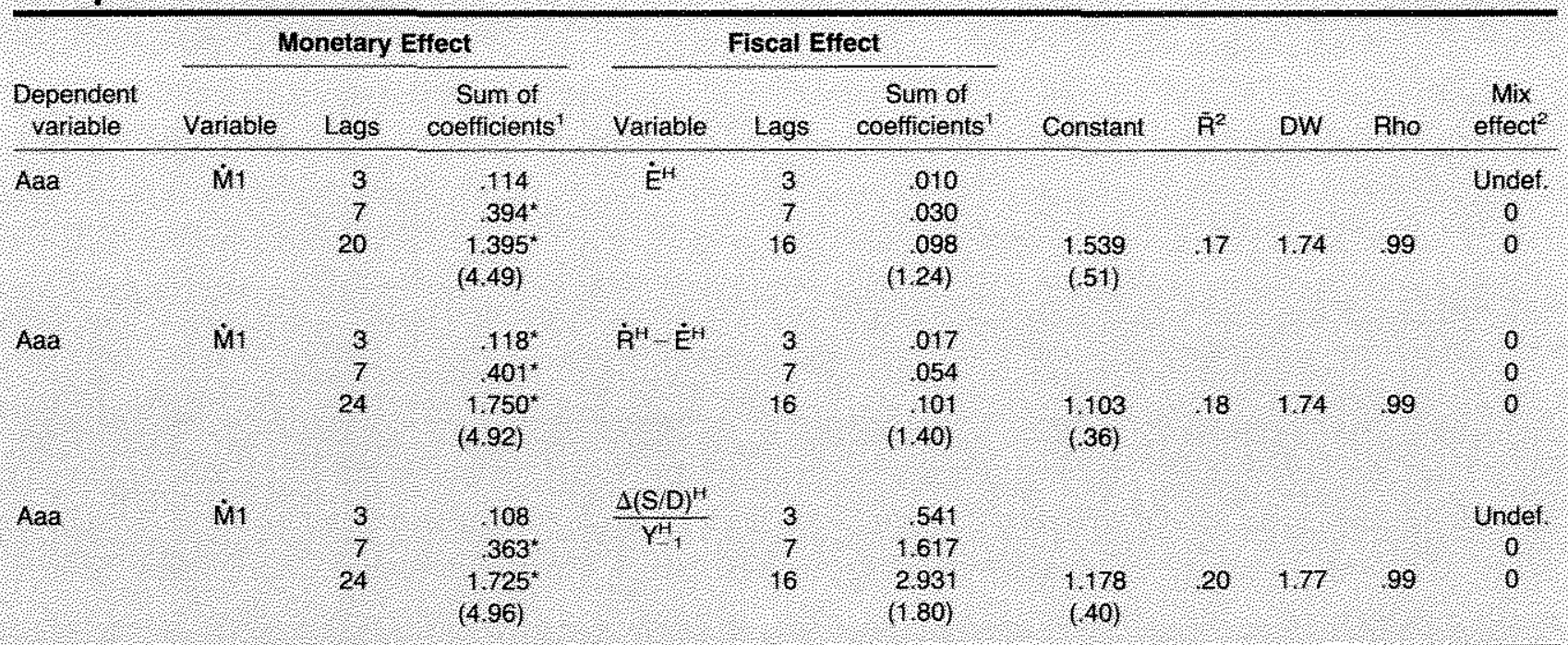

SSums are eumulative for number of legs indicated. Absolute value of tstatistic in parentheses, indicates sum is signilicant at 5 percent: level.

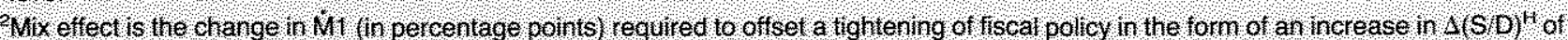
$\$ 5$ bilion To offset neans to keep the dependent variable unchanged See appendix for detals. Undel theans the mix effect is undefined, neither the nonetary or iscal effect is slgnificanly difterent ton zero (5 pelcent level)

Nominal interest rates and policy mix-Many analysts consider the level of nominal interest rates to be the primary cause for the current economic malaise. Yet the IS-LM model depicts the interest rate as a dependent variable. So, the first question investigated here is whether the nominal interest rate is systematically related to monetary-fiscal actions. The relationship of the corporate Aa bond rate to the selected measures of monetary and fiscal policy is summarized in table 4.

Three regressions were run, corresponding to the three measures of fiscal action. The number of lags that maximized the adjusted $\mathrm{R}^{2}$ of the equation ranged from 20 to 24 for M1 and was 16 for the fiscal variable. The results are summarized as one-year effects (current and three lags), two-year effects (current and seven lags), and the full effect, which takes into account all of the lags. Relevant summary statistics also are shown.

According to the simple IS-LM interpretation as shown in figure 2, a tighter fiscal policy should be accompanied by a tighter monetary policy in order to keep interest rates unchanged. Remember that the model of figure 2 ignores the infuence of price expectations. A tightening of fiscal policy with no change in monetary policy shifts the IS curve to the left, leading to a fall in interest rates. To keep interest rates unchanged, monetary policy would have to be tightened, shifting the LM curve to the left. Consequently, the implication of the simple IS LM model is that the "mix effect" would be negative.

The results in table 4 are clear-cut. The mix effect is either zero or undefined. The effect of $\dot{\mathrm{E}}^{\mathrm{H}}$ on interest rates is of the expected sign, but not significantly different from zero. In the case of both $\dot{\mathrm{R}}^{\mathrm{H}}-\dot{\mathrm{E}}^{\mathrm{H}}$ and $\frac{\Delta S / D^{H}}{Y_{-1}^{\mathrm{H}}}$, the effect on interest rates is not of the expected sign, but is also not significant. A tightening of fiscal policy, that is, an increase of $\dot{\mathrm{R}}^{\mathrm{H}}-\dot{\mathrm{E}}^{\mathrm{H}}$ or $\frac{\Delta \mathrm{S} / \mathrm{D}^{\mathrm{H}}}{\mathrm{Y}_{-1}^{\mathrm{HH}}}$, is associated with an increase in interest rates. The effect of monetary policy on interest rates in all cases is positive, ruming contrary to the implication of the simple IS-LM model.

In general, fiscal policy has no effect on the Aaa bond rate; thus, there is no mix effect. The effect of monetary expansion, on the other hand, builds up over time and appears to be permanent. These results suggest that it is necessary to augment the IS-LM model with price 
Table 5

Effects of Monetary and Fiscal Actions on a Proxy for the Real Interest Rate Sample Period: II/1959-IV/1981

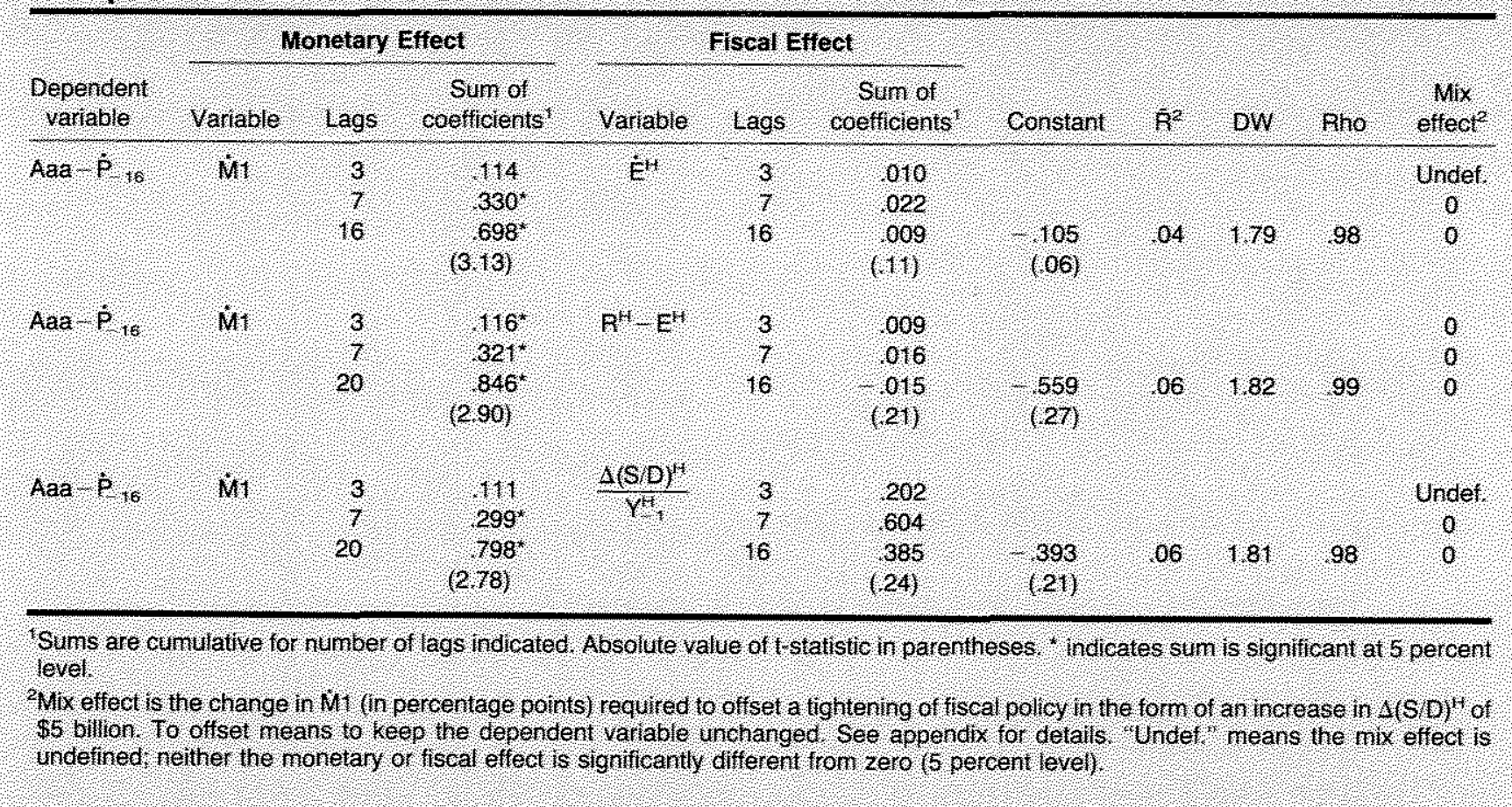

expectations, when those expectations seem to depend on the rate of monetary expansion. The explanatory power of each of the three equations is dominated by the rate of change of money.

Real interest rates and policy mix-Recent concern about the level of interest rates also has been couched in terms of the real rate. ${ }^{15}$ Many consider the current high level of real rates an obstacle to economic recovery. Since real rates are not observable, however, proxies have to be developed. Although much work has been done, the simple proxy of a nominal rate minus the recent rate of inflation is still most commonly used. For this analysis, the real rate is proxied by the Aaa bond rate minus the rate of change of the GNP deflator over the four previous years.

The results are summarized in table 5, following the same format as before. The explanatory power of each equation is very low, although the monetary effect is significant in each case. The fiscal effect is not signifi-

\footnotetext{
${ }^{15}$ See, in paticular, the study by the Congressional Budget office cited in footnote 3 .
}

cant for any of the three measures. As with nominal rates, there is no mix effect applicable to the real rate.

In general, monetary and fiscal actions do little to explain the movement of the real rate as measured by the Aar bond rate minus past inflation. To the extent that the equation has explanatory power, it comes from the monetary variable. Even that effect runs counter to the conventional wisdom, as might be implied by an expectations-augmented IS-LM model. More expansionary monetary policy is associated with increases in the real rate. Such an effect should probably not be taken too seriously, however, because of the problems inherent in measuring the real rate.

Output growth and policy mix-Another interpretation of the mix problem is that output growth is being retarded by the particular combination of policies in effect. The next set of regressions examines the rate of output growth as a function of the monetary and fiscal variables. These results are summarized in table 6 .

The monetary and fiscal variables explain between 35 and 40 percent of the movement of output growth, and no correction for serial correlation is necessary. What is apparent from these regressions is the impor* 
Table 6

Effects of Monetary and Fiscal Actions on the Rate of Output Growth Sample Period: II/1959-IV/1981

\begin{tabular}{|c|c|c|c|c|c|c|c|c|c|c|c|}
\hline \multirow[b]{2}{*}{$\begin{array}{l}\text { Dependent } \\
\text { varabble }\end{array}$} & \multicolumn{3}{|c|}{ Monetary Efect } & \multicolumn{3}{|c|}{ Flscal Ettect } & \multirow[b]{2}{*}{ Constant } & \multirow[b]{2}{*}{$\mathrm{R}^{2}$} & \multirow[b]{2}{*}{$\mathrm{OW}$} & \multirow[b]{2}{*}{ Rio } & \multirow[b]{2}{*}{ Motect } \\
\hline & Valable & Lags & Sunt of & Varabe & Lags: & $\begin{array}{l}\text { Sum of } \\
\text { coefficients }\end{array}$ & & & & & \\
\hline$x$ & N1 & $\begin{array}{l}3 \\
7 \\
20\end{array}$ & $\begin{array}{r}1010^{\circ} \\
434 \\
(001\end{array}$ & 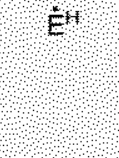 & $\begin{array}{l}3 \\
12\end{array}$ & $\begin{array}{r}030 \\
092 \\
307 \\
(70)\end{array}$ & $(4805)$ & 39 & 2.28 & $\mathrm{NA}$ & $\begin{array}{l}\text { Undef } \\
\text { Undef }\end{array}$ \\
\hline $\mathrm{X}$ & Mt & $\begin{array}{l}3 \\
? \\
20\end{array}$ & 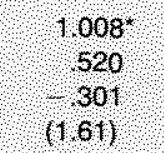 & $\mathrm{H}^{\mathrm{H}} \mathrm{E}$ & $\begin{array}{l}3 \\
7 \\
2\end{array}$ & $\begin{array}{l}0082 \\
0082 \\
(120)\end{array}$ & $\begin{array}{l}4.506 \\
(4.61)\end{array}$ & 37 & 220 & $\mathrm{NA}$ & $\begin{array}{l}\text { Undef } \\
\text { Undef: }\end{array}$ \\
\hline 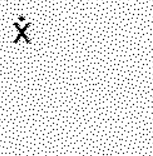 & $\mathrm{n} 1$ & $\begin{array}{l}3 \\
7 \\
20\end{array}$ & $\begin{array}{c}4076 \\
670 \\
270 \\
(56)\end{array}$ & $\frac{\mathrm{SSO})^{\mathrm{S}}}{\mathrm{U}}$ & $\begin{array}{l}3 \\
12\end{array}$ & $\begin{array}{r}2776 \\
3,29 \\
(946)\end{array}$ & 4.279 & 39 & 225 & $\mathrm{NA}$ & Undef \\
\hline
\end{tabular}

ISums are cunutative for number of lags indicaled, Absolite value of t statistic in parentheses. 1 hdicates sum is significant at 5 percent level

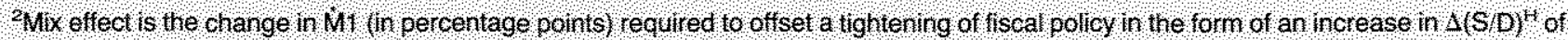
$\$ 5$ bilion, To offset means to keep the dependent variable unchanged See appendix for details. Undef 7 rieans the mix effect is undefined, neither the monetary or iscal effect is significantly difle ent from zero ( 5 percent level).

tance of the length of horizon. Money growth stimulates output growth in the short run, but this stimulus fades after a year. Consequently, any potential mix effect is applicable only in the short run, but none is found because the fiscal effect on output is not significantly different from zero.

The conventional wisdom indicates that a tightening of fiscal policy should be accompanied by an expansionary monetary policy in order to achieve a given rate of output growth. The directions of the effects are generally found, but, because the fiscal effect is not significantly different from zero, there is no mix effect. And, for the long term, the mix effect is undefined because neither the effects of monetary or fiscal actions are significantly different from zero.

Investment ratio and policy mix-A final variable of interest to those concerned with the current mix of policies is the investment ratio. Easy fiscal policy is thought to discourage private investment because the federal govermment preempts the use of loanable funds (see figure 2). To investigate this effect, the change in the ratio of fixed investment to GNP is run against the monetary and fiscal variables. Table 7 summarizes the results.
The striking feature of these regressions is that the explanatory power of these equations is quite high, with about 55 percent of the movement in the investment ratio explained by the monetary and fiscal variables. Also, no correction for serial correlation is necessary. The effect of monetary policy on the investment ratio is first positive, then negative (shown by a decline in the sum of coefficients as the horizon is lengthened); only in combination with $\dot{\mathrm{E}}^{\mathrm{H}}$ is the effect significant after 20 quarters. The fiscal effect, on the other hand, builds up over time and is significant at the 95 percent level after 16 quarters for each of the three fiscal variables.

The mix effect for the investment ratio, according to conventional wisdom, should be negative. A tightening of fiscal policy should be accompanied by a tightening of monetary policy in order to keep the investment ratio constant. That is, a tightening of fiscal policy is supposed to encourage investment; if that is to be offset, monetary policy also should be tightened. For all cases in table $\vec{i}$, the conventional wisdom is upheld. But, as the horizon is lengthened, there really is no mix effect, because monetary actions do not have a perma- 
Table 7

Effects of Monetary and Fiscal Actions on the Investment Ratio Sample Period: II/1959-IV/1981

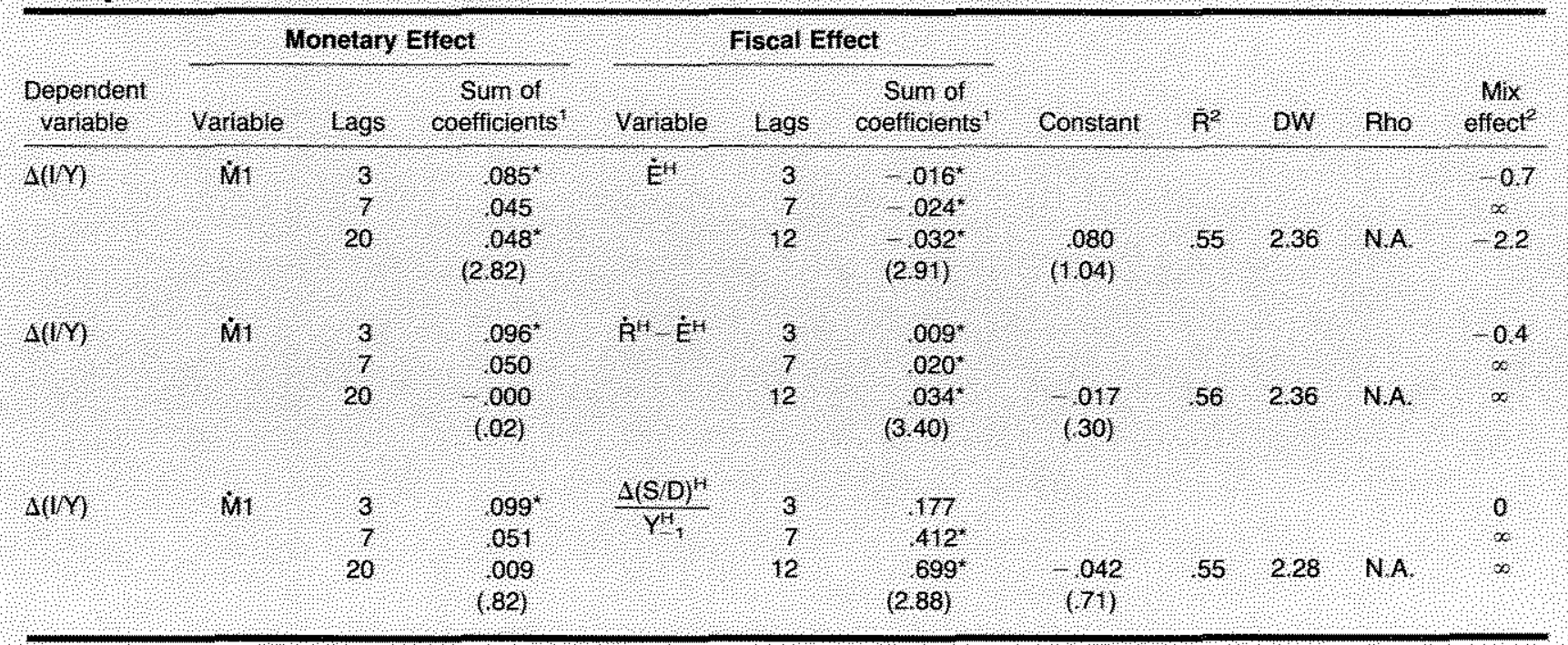

Sums are cumulatve for number of lags indicated Absolute value of $t$-statistic in parentheses, 2 indicates sum $1 \mathrm{~s}$ significant at 5 percent level:

MMx effect is the change in M1 (in percentage points) requited to offset a fightening of fiscal policy in the form of an increase in $\Delta(S \mathrm{D}) \mathrm{H}$ of $\$ 5$ bilion, to offset means to keep the dependerit variable unchanged. See appendix lor details, $\alpha$ neans the mix effect is infinite, that is, a nonzero effect is divided by zero, the fiscal effect is significant but the nonetary effect is not ( 5 percent level).

nent effect on the investment ratio, while fiscal actions do (this result is shown as $\infty$ ).

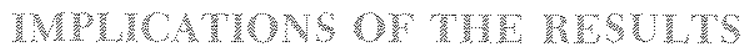

These regression results carry certain implications for economic policy that are at variance with the conventional wisdom on policy mix. The general policy implications of the statistical results require further discussion. To give some indication of the magnitude of effect, some different policy mixes are simulated for the period from 1981 to 1985 .

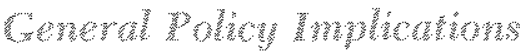

These regression results can be pulled together into a general conclusion. Consider Tobin's recommendation, cited at the beginning of this paper:

To achieve a solid recovery, such as the administration projects, and to achieve it without astronomical interest rates and serious crowding out, we need an easier monetary policy combined with a tighter fiscal policy.

What light do these regression results shed on this recommendation? First, if easier monetary policy means faster money growth, following Tobin's recommendation will yield nominal interest rates that are higher, not lower. The implication for real rates is not clear; even though real rates were positively related to money growth, the regressions were not significant. To the extent that interest rates can be explained, money growth, not fiscal actions, provides the explanation. An easing of fiscal policy alone does not guarantee a fall in interest rates. The effect of fiscal actions on interest rates was not found to be significant.

The idea of a solid recovery is that real output growth could be stimulated by shifting the mix toward tighter fiscal policy and easier monetary policy. The regression results indicate that this desired effect could be achieved, but only temporarily. Fasier monetary policy stimulates output growth initially, but this effect dissipates after a year. Furthermore, the regression results indicate that fiscal effects on output growth are not significant, either in the short or long run.

Tobin's recommendation has some validity in its assertion that the mix should be changed to avoid "serious crowding out." ${ }^{\text {"16 }}$ According to the regression

\footnotetext{
${ }^{16}$ For a survey article on "crowding out," see Keith $\mathrm{M}$. Canlson and Roger W. Spencer, "Crowding Out and Its Critics," this Review (December 1975), pp. $2 m 17$
} 


\section{Table 8}

\section{Simulation of Alternative Policy Mixes}

\begin{tabular}{|c|c|c|c|}
\hline & $\begin{array}{l}\text { Easy fiscal Policy } \\
\text { and } \\
\text { Tight Monetary Policy }\end{array}$ & $\begin{array}{l}\text { Toht Fiscal Pollcy } \\
\text { and } \\
\text { Tight Monetary Policy }\end{array}$ & $\begin{array}{l}\text { Tight Fiscal Policy } \\
\text { and } \\
\text { Easy Monetary Policy }\end{array}$ \\
\hline \multicolumn{4}{|l|}{ Corporate Aaa Bond Fate } \\
\hline 1981 Actual & $1417 \%$ & $14.17 \%$ & $14,17 \%$ \\
\hline 1982 & 1426 & 4.28 & $\$ 4.39$ \\
\hline 1983 & 13.01 & 13,26 & 13.78: \\
\hline 1984 & 1137 & 1200 & 13,16 \\
\hline 1985 & 999 & 10.87 & 1282 \\
\hline \multicolumn{4}{|l|}{ Growth Rate of Real GNP } \\
\hline $\begin{array}{l}1981 \text { Actual } \\
\text { a }\end{array}$ & $0,80 \%$ & $0.80 \%$ & $0.80 \%$ \\
\hline 1982 & $-0,3$ & -0.35 & 1.36 \\
\hline 1983 & 216 & 110 & 284 \\
\hline 1984 & 310 & 214 & 254 \\
\hline 1985 & 3.67 & 341 & 283 \\
\hline \multicolumn{4}{|l|}{ Investment Ratio } \\
\hline $3 \quad 1981$ Actual & $15,36 \%$ & $1536 \%$ & $1536 \%$ \\
\hline 1982 & 14,62 & 1464 & 15.00 \\
\hline 1983 & 1396 & 1419 & 1524 \\
\hline 1984 & 1343 & 1416 & 1548 \\
\hline 1985 & 1295 & 1452 & 15.73 \\
\hline
\end{tabular}

NOTE Easy fiscal polcy is a steady increase of the high-employment defict to $\$ 150$ billon in fiscal 1985 Tight fiscal policy is a steady movenent toward a balanced highemployment budget in fiscal 1985 Easy monetary policy is 6.5 percent growth rate of M1 Tight monetary policy is 4.5 petcent growth rate of $M 1$

results, tighter fiscal policy would indeed encourage a rise in the investment ratio, but interest rates would be minimally affected. This shift to tighter fiscal policy, however, need not be accompanied by easier monetary policy. There is a positive effect of monetary actions on the investment ratio, but it appears to be temporary, whereas the fiscal effect appears to be permanent.

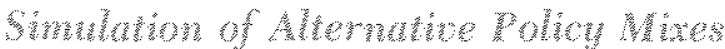

To provide some specific indication of the magnitudes involved in the policy mix controversy, the regression results were used to simulate three different mixes of policy for the 1982-85 period. Point estinates of the coefficients were used even if they were not significantly different from zero. ${ }^{17}$

Two fiscal scenarios were chosen; one is based on fiscal actions that lead to a $\$ 150$ billion deficit in the high-employment budget by 1985 , the other a tighter

\footnotetext{
Fipeal inferest rates were not simulated because none of the regres sions was signiffunt.
}

fiscal policy that yields a balanced high-employment budget by 1985 . The easy policy conforms rotghly with the prospective course of fiscal action as it appeared to be developing in early 1982 . The tight policy is consistent with a recommendation by the Brookings Institution in their annual report on the federal budget. ${ }^{\text {is }}$

Two monetary policies were simulated: one is a steady expansion of M1 at a 4.5 percent rate, the other is expansion at a 6.5 percent rate. The first policy is labeled "tight" and would be within the 1982 target range announced by the Federal Reserve. The 6.5 percent scenario for money is called "easy," and would be above the upper end of the 1982 target range.

Table 8 gives the results of these simulations. The result of tightening fiscal policy and easing monetary policy (compare the first and third columns) is to push up nominal interest rates. The growth of output is

\footnotetext{
"See Chates L. Schultre, "Long-Term Budget Strategies," in Toseph A Pedmun, ed. Setting National pronities: The 1983 Budget (The Brookings Institution, 1982), pp. 187-220. Their recommendation was made before passage of the Tax Equity and Fiscal Responsinility Aet of 1982.
} 
actually worsened by the change in the mix, the reason being that inflation accelerates with easier monetary policy. The investment ratio, however, is increased by changing the mix of policy. As the middle column of table 8 shows, there is little to be gained by expanding money more rapidly when fiscal policy is tightened. Although easing monetary policy appears desirable because of its beneficial effects on fixed investment, recall that the long-run effects of money growth on the investment ratio were not statistically different from zero.

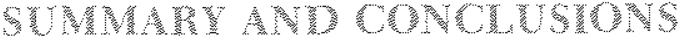

The notion of policy mix has been presented in textbooks and discussed by eminent analysts almost as if it were a self-evident truth. A recommended change in policy mix seems to be based on the well-known IS-LM model. When scrutinized more closely, the question of the appropriate mix of monetary-fiscal policies is not as clear-cut as the simple IS-LM model implies. The lagged effects of policy actions must be taken into account, as well as the empirical realities of certain economic relationships.

This paper examined four dependent variables that seem relevant in any discussion of policy mix-nominal interest rates, real interest rates, the rate of output growth, and the investment ratio. The conclusions are as follows:

(1) Movements of nominal interest rates and, to a lesser extent, real rates are dominated by monetary actions. The effect of fiscal actions on interest rates is not statistically significant.

(2) There is a short-rute effect of monetary actions on output growth, but it is only temporary. Over the long run, movements in output growth are unaffected by either monetary or fiscal actions.

(3) The investment ratio is influenced temporarly by monetary actions, but the effect appears to be permanent for fiscal actions.

These conclusions imply that the IS-LM framework must be carefully interpreted when used as a guide for policy analysis, and that current recommendations for a change in the mix are only partly valid. Fiscal policy should indeed be tightened in order to stimulate an increase in the investment ratio, if long-term economic growth and/or housing investment is a national goal. There is little evidence, however, to support the notion that interest rates would be affected greatly. There is no basis for thinking that a tightening of fiscal policy should be accompanied by an easing of monetary policy. The effect of easier monetary policy would be higher nominal interest rates and only a temporary surge of output growth. 


\section{Appendix}

\section{Change in Fiscal Policy Used in Calculating Mix Effect}

\begin{tabular}{|c|c|c|c|c|c|c|c|c|c|c|c|c|}
\hline & \multicolumn{6}{|c|}{ Actual Fiscal Policy (High Employment Values) } & \multicolumn{6}{|c|}{ Tighter Fiscal Pollcy (High-Employment Values) } \\
\hline & \multicolumn{2}{|c|}{ Receipts } & \multicolumn{2}{|c|}{ expendures } & \multicolumn{2}{|c|}{ surpus betielt } & \multicolumn{2}{|c|}{ Recelpts } & \multicolumn{2}{|c|}{ Expendifures } & \multicolumn{2}{|c|}{ surpus Geflot? } \\
\hline & Level & Change & Level & ohang & Gevel & Change & level & Change & Level & Change & (sevel & Change \\
\hline 1980.1 & $\$ 5423$ & $\$ 14.5$ & $\$ 5606$ & \$25. & $\$ 88$ & $\$ 10.6$ & 85423 & $\$ 145$ & $\$ 5556$ & $\$ 201$ & $\$ \$ 13.3$ & 85.6. \\
\hline मा & 5575 & 152 & 579,3 & 187 & $(-2,7$ & 1.9 .4 & 5576 & 152 & 5693 & 13.7 & (4) & 16 \\
\hline III: & 580, & 226 & 604,4 & 25, & 4242 & -25 & 5801 & 226 & 5894 & 201 & 1792 & 25 \\
\hline $\mathrm{N}$ & 6135 & 33.4 & 630,3 & 259 & 416.8 & 974 & 6135 & 334 & 6103 & 20.9 & 3.2 & 12.4 \\
\hline 19811 & 650.2 & 367 & 6514 & 211 & 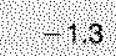 & 155 & 6502 & 367 & 6264 & 16.1 & 237 & 206 \\
\hline - 1 & 6633 & 131 & 6528 & 144 & 10.6 & 1749 & 6633 & 131 & 6228 & -36 & 40.6 & 18.9 \\
\hline Il: & 6847 & 214 & 6804 & 276 & 443 & 460 & 6847 & 214 & 6454 & 226 & 393 & प्र 1.3 \\
\hline IV & 6883 & 36 & 112,2 & 978 & 24.0 & 28.3 & 6883 & 3,6 & 6722 & 26.8 & 160 & 23.3 \\
\hline
\end{tabular}

For the fiscal variables used in the regressions, his change in polley translates as tollows:

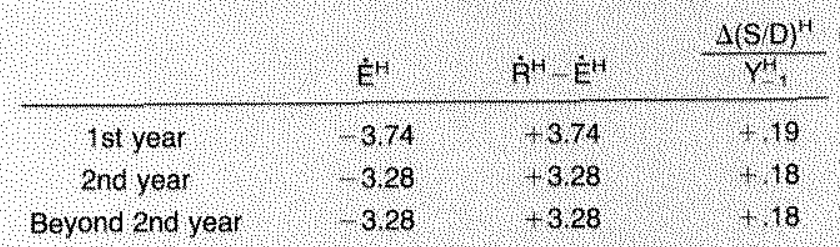

